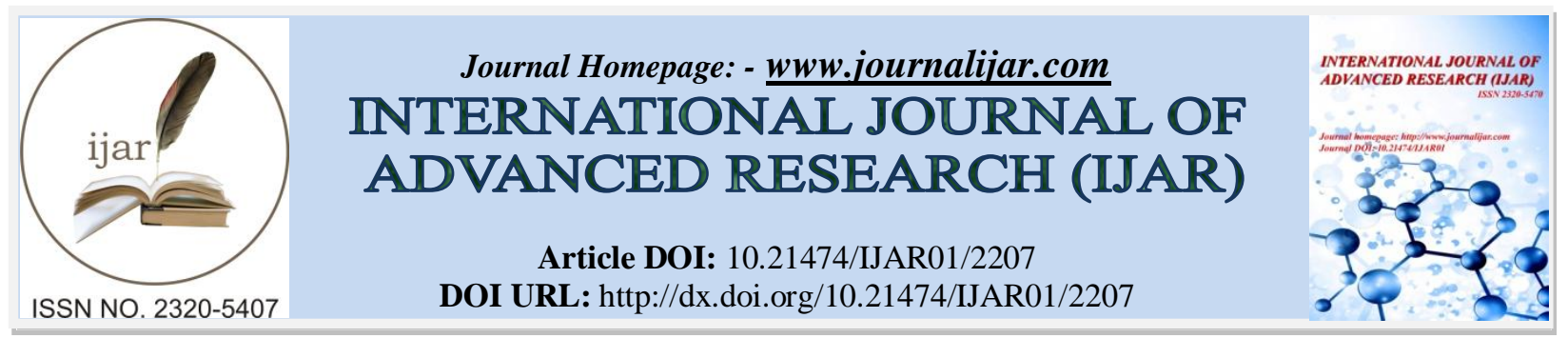

RESEARCH ARTICLE

PSYCHE- SOCIAL SUPPORT FOR THE RAPE VICTIMS IN DAR FUR REGION.

Dr. Madina Hussien Dousa.

Assistant professor . Sudan Nyala University: Kingdom Of Saudi Arabia. Buraydah private Colleges.

\section{Manuscript Info}

Manuscript History

Received: 28 September 2016

Final Accepted: 30 October 2016

Published: November 2016

Key words:-

Rape, victims, psychosocial support, Dar Fur

\begin{abstract}
This study is about sexual violence mainly rape of women $\&$ girls in Dar fur as a conflict zone $\&$ how assist the victims psychosocially, the study addressed the issue by introducing the rape as a concept from evolutionary point of view \& feminists ones \& highlighted the rape of women in war times of the worldwide $\&$ the efforts of international humanitarian law in criminalizing the act .

The study provided the documented reports \& incidents which reflected the miserable situation of the victims (women \& girls) \& the impacts of such crime socially \& psychologically the study brought some strategic plans \& approaches assisting victims psycho socially \& focused on the psycho- social support mainly WNGOs $\&$ justified their significant support of victims . It concluded with a series of recommendations, based on the social scientific evidence presented in the study.
\end{abstract}

Copy Right, IJAR, 2016,. All rights reserved.

\title{
Introduction:- Introduction:-
}

After all I am here writing this article not intend to Judge or rationalize positively or negatively the rightness or wrongness of any party for sexual crimes committed in Dar Fur . but sometimes as psychologist \& gender specialist may feel there necessity of contributing even by words although they have minim influence nowadays, \& professionally want to write mainly to help civic organizations, who deal with (survivors) who faced terrifying conditions, an injury to them is an injury to all of us . This article based on four basic issues : firstly literature review of rape as a concept, \& stages for legalization rape as a crime of war.

Secondly: Rape incidents in Dar Fur as a conflict context. Thirdly : the kind of psycho - social problems that rape survivors experience. Fourthly: look for strategies for psycho social support \& advocacy groups mainly local Non-Governmental organizations (NGOs) to deal with survivors

The objectives of the article lay in following points

- To introduce the concept of rape

- To Introduce rape in Dar Fur as a matter of fact

- To suggest strategies for local NGOs to provide psychosocial support for survivors of rape

- To stand in solidarity with our sisters in Dar Fur who faced terrifying conditions. An injury to one is an injury to all! 
Rape as a concept : The word rape is derived from the Latin word rapere meaning to steal, seize or carry away. Rape is the oldest means by which a man seized or stole a wife. A man simply took whichever woman he wanted, raped her, and then brought her to his tribe as his possession. The American Heritage Dictionary ${ }^{1}$ defines rape as crime of forcing a female to submit to sexual inter course . The International Criminal Court, defines rape as the perpetrator invaded ${ }^{2}$ the body of a person by conduct resulting in penetration, however slight, of any part of the body of the victim or of the perpetrator with a sexual organ, or of the anal or genital opening of the victim with any object or any other part of the body." ${ }^{3}$ the legal definition is carnal knowledge through the use of force or threat of force according to the Uniform Crime Reports ${ }^{4}$, all three definitions describe a violent infringement on the personal dignity of an individual. In many national and some international legal regimes rape is a crime, without reference or justification to any other legal principle or standard. In some legal regimes, rape is declared illegal as a result of its relation to other major legal principles. Rape has been conceptualized as: form of torture that violates human rights European Court of Human Rights (2010). Rape as a war crime as part of a widespread or systematic attack directed against any civilian population.

Rape is typically defined, in this article, as the use of force or threat of force to achieve penile-vaginal penetration of a woman without her consent . Rape of women by men has occurred throughout recorded history and across cultures. The raping of women is a crime on the increase in all of the world especially in war affected areas .

Rape is extensively used by those in power as a mean of control and to exert dominance and power over those who are most vulnerable ${ }^{5}$. Throughout history, it has seen the ways in which this form of abuse used during times of war and civil conflict to the extent that it has methodically become a weapon of war. This, however, has not remained in the past and is evident across the globe today in areas rife with conflict. Recently international reports from war affected societies ${ }^{6}$ were indicating that rape is increasingly being used as a weapon of war. In pain for women who silently sadly suffering of rape, there for it's the fact of life across cultures (Roze'e1993; Sanday, 1981). In American samples, estimates 13\% ( Kilpatrick, Edmunds, \& Seymour, 1992) however , because rapes often go

1. American Heritage Dictionary of the English Language, Fifth Edition (2011).

${ }^{2}$. The invasion was committed by force, or by threat of force or coercion, such as that caused by fear of violence, duress, detention, psychological oppression or abuse of power, against such person or another person, or by taking advantage of a coercive environment, or the invasion was committed against a person incapable of giving genuine consent.[The concept of "invasion" is intended to be broad enough to be gender-neutral and the definition is understood to include situations where the victim may be incapable of giving genuine consent if affected by natural, induced or age-related incapacity. ${ }_{\text {see :Minzoni - Deroche, Angela (November 2005). "Rape as a tactic of war - Advocacy Paper" (PDF). Caritas France.[dead }}$ link[

${ }^{3}$. Jump up to: a b Elements of Crimes at the Wayback Machine (archived December 1, 2008). PDF: Archive copy at the Internet ArchivePDF. International Criminal Court

${ }^{4}$.The Uniform Crime Reporting (UCR) Program has been the starting place for law enforcement executives, students of criminal justice, researchers, members of the media, and the public at large seeking information on crime in the nation. The program was conceived in 1929 by the International Association of Chiefs of Police to meet the need for reliable uniform crime statistics for the nation. https://ucr.fbi.gov/

${ }^{5}$. The fact that rapes regularly occur during war time has been presented as evidence of the assessment of victim vulnerability and decreased likelihood of detection . Men in war are likely to have lowered costs of committing rape, because punishment or retaliation by the victim, the victim's family, or society, are particularly is less likely. For more details see: Gottschall, J. (2004). Explaining wartime rape. TheJournal of Sex Research, 41, 129-136.

${ }^{6}$. UN agencies estimate that more than 60,000 women were raped during the civil war in Sierra Leone (1991-2002), more than 40,000 in Liberia (1989-2003), up to 60,000 in the former Yugoslavia (1992-1995), and at least 200,000 in the Democratic Republic of the Congo since 1998.In Rwanda, between 100,000 and 250,000 women were raped during the three months of genocide in 1994. See:Overview of the worldwide best practices for rape prevention and for assisting women victims of rape www.europarl.europa.eu/RegData/etudes/.../IPOL-

FEMM_ET(2013)493025_EN.pdf 
unreported, researchers estimate that $67-84 \%$ of rapes are not reported ${ }^{7}$. In the past rape was seen as the expression of an overwhelming sexual urge, one that women could invite by provocative dress or behavior ${ }^{8}$. In order to analyze rape one almost needs some philosophical approaches however, throughout the past 20 years many psychologists and sociologists have begun to study the psychology of rape. Their findings have shown that rape is a crime of violence, often regarded by the woman as a life threatening act in which fear and humiliation are her dominant emotions. Sexual desire is less a motivation for the man than violent aggression, bearing those findings in mind \& taking evolutionary theory \& feminist approaches as umbrellas \& conceptual frames .so to analyze rape from an evolutionary psychological perspective ${ }^{9}$. The basic Principles of this theory lays in : to understand the complexity of human behavior one must take human evolutionary history in to account as well as natural selection. Men have evolved psychological mechanisms that motivate them to rape in specific contexts. Behavior depends on evolved psychological mechanisms. Evolved psychological mechanisms are functionally specialized to perform a specific task or to solve a specific problem that recurrently affected reproductive success over evolutionary. The numerousness premise states that human brains consist of many specific evolved psychology.

On the other hand, there many magazines, academic journals, and human rights publications and academic presentations \&a lot of literature review has been produced in criticizing evolutionary perspective which justifies or legitimizes rape \& provides false beliefs of behavior`s unalterable, unchangeable. The opposes stated that no evolutionary psychologist argue that because rape is produced by evolved mechanisms, we should accept its occurrence. Providing the perspective of evolutionary one does not justify this heinous act but to come beyond greater understanding of the causes of rape, which may help others prevent its occurrence .Evolutionary psychologists have been at pains to show that rape is actually a sexual crime through which men seek sexual gratification from women who would otherwise refuse them. On the other hand analyze rape from Feminist perspective $^{10}$ writers see rape as an extension of a male-dominated society's control over females. Since the stone age, women have been viewed as possessions of first their fathers, and then of their husbands. In the old testament, we are told that shalt not covet thy neighbor`s house, thou should not covet they neighbor`s wife. .., nor anything that is thy neighbors ${ }^{11}$ little girls are taught to be passive and little boys to be aggressive. When these stereotypes become extended to our sexual roles, some people feel that women want to be sexually dominated by men, and that men have the right to demand sexual compliance from any female. In regarding these perspectives one of the most fruitful conclusion within the above discussion is that : Rape is a woman`s issue ${ }^{12}$ because, it is the woman who is the victim. However, it is a man`s issue too, because women who have been raped need the support and understanding of all those around them including their fathers, brothers, husbands, and friends. Despite the fact that rape and other forms of sexual violence had been prohibited by the laws of armed conflict for centuries, whether traditionally or according to the religion legalizations, on the other hand rape in conflict was tacitly accepted for centuries as unavoidable, because historically, armies considered rape one of the legitimate ${ }^{13}$ spoils of war. One of the first references to the, "traditions of war" was Cicero, who urged soldiers to observe the rules of war.

7. Rang ham, R.,\& Peterson, D. (2007). Demonicmales. New York: Houghton Mifflin. For more see Greenfield, L. (1997). Sex offenses and offenders. Washington, DC: Bureau of Justice Statistics, U.S. Department of Justice.

${ }^{8}$. individuals with this belief often unintentionally place the victim on trial. Her motives, her dress and her actions become suspect not only to law enforcement officials but also to her family and friends. The woman`s credibility may be questioned and her sexual activity and private life may be made public. Perhaps because of the guilt, embarrassment and humiliation.

${ }^{9}$.Evolutionary psychology is a powerful heuristic tool that allows researchers to develop and test novel hypotheses about complex behaviors such as rape for a more complete review, seeBuss, 2004; Tooby\&Cosmides, 2005)

${ }^{10}$. although within the feminism movement there different feminists( liberal, radical, social) \& several theoretical models

${ }^{11}$. Marcia Cohen and Sherrie H. McKenna .(2016) . Rape: Psychology, Prevention and Impact, Yale-New Haven Teachers Institute Home

12. except in those rare instances of homosexual rape,

13 . Conquering the riches and property of an enemy was regarded as legitimate reason for war in itself. Women were included with "property", since they were considered under the lawful ownership of a man, whether a father, husband, slave master, or guardian. ^ Jump up to: ${ }^{a b c}$ Askin (1997), pp. 10-21 
Theoretically Susan Brown miller was the first historian to attempt an overview of rape in war with documentation and theory. ${ }^{14}$ Brown miller's thesis is that "War provides men with the perfect psychological backdrop to give vent to their contempt for women. The maleness of the military.

Kelly Dawn Askin, stated that the laws of war perpetuated the attitude that sexual assaults against women are less significant crimes, not worthy of prosecution ${ }^{15}$. In 1159, John of Salisbury wrote Policraticus believed that acts of theft and "rapine" (property crimes) should receive the most severe punishment, in the 15th and 16th century, despite considerations and systematization of the laws of war, women remained objects available to the conquering male in any way whatsoever. In overviewing the historical background of war rape in nations \& examples from some societies . take the ancient Greeks in consideration, so war rape of women "socially acceptable behavior well within the rules of warfare" ${ }^{16}$. In medieval Europe, women were considered as an inferior gender by $\operatorname{law}^{17}$ The $^{2}$ Catholic Church sought to prevent rape during feudal warfare through the institution of Peace and Truce of God which discouraged soldiers from attacking women and civilians in general and through the propagation of a Christianized version of chivalry ideal of a knight who protected innocents and did not engage in lawlessness. According to Fadl, Medieval Islamic military jurisprudence laid down severe penalties for those who committed rape $^{18}$ The punishment for such crimes were severe, including death, regardless of the political convictions and religion of the perpetrator.

.In the late Middle Ages, the laws of war even considered war rape as an indication of a man's success in the battlefield and "opportunities to rape and loot were among the few advantages open to... soldiers, who were paid with great irregularity by their leaders....triumph over women by rape became a way to measure victory, part of a soldier's proof of masculinity and success, a tangible reward for services rendered....an actual reward of war" ${ }^{19}$ The first formal prosecution for violations of war crimes did not take place until the late Middle Ages ${ }^{20}$. According to Human Rights Watch rape in war times has recently been a hidden element of war, linked to the largely genderspecific character of war rape.

Hugo Grotius, considered the father of the law of nations and the first to conduct a comprehensive work on systematizing the international laws of war, concluded that rape "should not go unpunished in war any more than in peace" In the 19th century, the treatment of soldiers, prisoners, the wounded, and civilians improved and core elements of the laws of war were put in place However, while the customs of war mandated more humane treatment of soldiers and civilians, new weapons and advanced technology increased destruction and altered the methods of war. ${ }^{21}$ The Lieber Code (1863) was the first codification of the international customary laws of land war and an important step towards humanitarian law emphasized on protection of civilians and stated that "all rape...[is] prohibited under the penalty of death", which was the first prohibition of rape in customary humanitarian law. ${ }^{22}$ During the 20th century, international legal procedures attempted to prevent and prosecute perpetrators of war

${ }^{14}$.^ Jump up to: $\frac{a b c}{}$ EijiTakemae, Robert Ricketts, Sebastian Swann, Inside GHQ: The Allied Occupation of Japan and Its Legacy. p. 67. (Google.books)

${ }^{15}$. Jump up ^Askin (1997), p. 13

${ }^{16}$. Jump up to: ${ }^{a b c}$ Askin (1997), pp. 10-21

.Jump up ^Askin (1997), pp. 23-24

18 . ^ Jump up to: ${ }^{a b}$ Abou El Fadl, Khaled (2001). Commentary: Terrorism Is at Odds With Islamic Tradition. LA Times. Retrieved 11 July 2011

${ }^{19} \cdot{ }^{\wedge}$ Jump up to: ${ }^{a b}$ Askin (1997), p. 27

20.^ Jump up to: ${ }^{a b}$ Askin (1997), p. 28

${ }^{21}$ Jump up ^Askin (1997), p. 33

${ }^{22} .^{\wedge}$ Jump up to: ${ }^{a b}$ Askin (1997), pp. $35-36$ 
rape. Similarly, individual states developed laws pertaining to war rape's victims and perpetrators. Article 46 of the Hague Conventions of 1899 and 1907 regarding Land Warfare explicitly required that "family honor and rights and the lives of persons...must be respected" by the occupying powers. ${ }^{23}$ No formal reference was made to sexual violence until World War II, two multinational war-crimes tribunals were established by the Allies to prosecute suspected war criminals, one in Tokyo, and the other in Nuremberg ${ }^{24}$. Thus subject of women's victimization was only given incidental attention in . international legal instruments to prosecute perpetrators but this has occurred as late as the 1990s. Article 27 of the 1949 Fourth Geneva Convention explicitly prohibits wartime rape and enforced prostitution in international conflicts. The prohibitions outlined in the 1949 Geneva Conventions were reinforced by the 1977 Additional Protocols I and II to the 1949 Geneva Conventions ${ }^{25}$.. The United NationsDeclaration on the Protection of Women and Children in Emergency and Armed Conflict, which went into effect in 1974, does not mention rape specifically.

In 1998-2007 the International Criminal Tribunal for Rwanda established by the United Nations made landmark decisions defining genocidal rape as a form of genocide under international law. rape has been regarded as spoils of war. Now it will be considered a war crime ${ }^{26}$. Some of the delegates to the Global Summit to End Sexual Violence in Conflict held in 2014. In 2008, the U.N. Security Council adopted resolution 1820, which noted that "rape and other forms of sexual violence can constitute war crimes, crimes against humanity or a constitutive act with respect to genocide"27. The Office of the Special Representative of the Secretary-General on Sexual Violence in Conflict (SRSG-SVC) was established by Security Council Resolution 1888 (2009). The office serves as the United Nations' spokesperson and political advocate on conflict-related sexual violence, and is the chair of the network UN Action against Sexual Violence in Conflict.

In 2016 the first conviction for war-related sexual violence occurred, when the International Criminal Court included rape in a war crimes conviction . here the words of -- George Clooney, actor and director, in Sept. 14, 2006 strongly present in mind when he address to United Nations Security Council : “ . . . When you see entire villages raped and killed, wells poisoned and then filled with the bodies of its villagers, then all complexities disappear and it comes down to simply right and wrong. It's not getting better. It's getting much, much worse. And it is only the international community that can help us."

Today, rape is widely recognized as a pervasive and brutal tactic of war that threatens international peace and security and leads to permanent injury, unwanted pregnancy, death\& the victims of modern armed conflict are far more likely to be civilians than soldiers. According to UN Action Against Sexual Violence in Conflict, the vast majority of casualties in today's wars are among civilians, mostly women and children. Women in particular can face devastating forms of sexual violence.

Rape in Dar Fur conflict ${ }^{28}$ :

\footnotetext{
${ }^{23}$ ^ Jump up to: $^{a b}$ Askin (1997), pp. 35-36

24. The trial of General Matsui who had the command of Japanese forces . Matsui was convicted of war-crimes and crimes against humanity based in part on evidence of rape committed by his troops.see ${ }^{25 \wedge}$ Jump up to: ${ }^{a b}$ Askin (1997), p. 17

${ }^{26}$. Statement said by NavanethemPillay. United Nations High Commissioner for Human Rights ${ }^{27}$. Jump up ${ }^{\wedge}$ "SECURITY COUNCIL DEMANDS IMMEDIATE AND COMPLETE HALT TO ACTS OF SEXUAL VIOLENCE AGAINST CIVILIANS IN CONFLICT ZONES, UNANIMOUSLY ADOPTING RESOLUTION 1820 (2008)". United Nations. Retrieved 2012-11-09

28. Darfur is a region in Sudan, that had a population of approximately 6 million. In 2003, two rebel groups, Sudan Liberation Army/Movement (SLA/M) and the Justice and Equality Movement (JEM) launched a full-scale rebellion against the Sudanese government for reasons of ongoing economic marginalization and insecurity.

The Sudanese government responded to the rebellion with the Arab militia (El- Janjaweed) with violent attacks on villages throughout the state. Since beginning in 2003 , an estimated 400,000 people have died directly or indirectly from the attacks.
}

deliberate and systematic extermination of a national, racial, political, or cultural group. The violence in Darfur is racially based \& considered as the worst humanitarian crisis of the 21 st century. 
so one can cry for traumatic child that horribly watching the brutal action for his/ her mother in front of his/her eyes . Cry for someone (survivors ) led by fault to be in such situation then who to be blamed !!! Cry for victims ${ }^{29}$ who violence committed against them they were helpless, hopeless, \& then they to be demanded to keep the customs ( silent it's shameful to speak about). Cry for whom personal freedom was violated \& see the guilty is walking around free!! Cry for victims who deny the event \& repressing their true feelings. Cry for the victims who subjected to unfair questions (the presence of semen so as to prove the incident). Cry for victims that have ostracized by closest friends because they narrated the horrible theme. cry for one who takes rags and sticks as shelter.Cry for lovely social fabric that has been destroyed. Cry for the beautiful cottage that has been burned. Cry for absence of the night dance under the moon of sliver shoon. Cry for the girls of cheerful faces that used to gather fire wood freely Cry for the happy ladies who used to walk for \& back to bring water from the well .Cry for returning cows under the sun set, cry for the uncle that sweeting but happily harvest the corn even under the burning sun but reassured\& secure. cry for the cowboy that waiting the goats \& sheep melodist songs with his local musical instrument at the seasonal green valley, cry for the singing birds on the trees That was Dar Fur now is no longer. No doubt conflict \& war is a social necessity \& a means which nations practice in order to solve their social problems but with deep concern the ongoing crisis in Dar Fur, where political and ethnic violence is threatening the stability and lives of the citizens. Women and children are at particular risk of being subjected to extreme harm during periods of conflict.

in dealing with this issue in this part of the article first I think I am lucky because talking about rape in war became less taboo. one almost needs neutrality \& transparency \& accountability in discussing such topic ,there a considerable amount of the existing data from UN reports, civic organizations interviews with the victims , journals, \& personal documents of the incidents, at the matter of fact some of these data sources are the products of research activity by well trained scientists. However some are combination of contradicting information one could imagine the nature of the results $\&$ possible biases or other inadequacies . of course a careful investigation of sources \& trustworthy ones` are being provided the following are specific points which drifted from literature review of the topic in reference to Dar Fur .

- Rape is the most common and usually first to be mentioned in the times of war. That exactly what happened in Dar Fur conflict.

- Women are vulnerable victims in times of crisis ( war) not because of their nature but the structures \& mechanisms that turn women in to victims.

- Rape is known as strategy of war $^{30}$ in some countries this what happened in Dar Fur

.There are numbers of reports ${ }^{31}$ that governments` regular forces have participated in the mayhem of sexual violence in Darfur, A mass of evidence indicates that Khartoum's regular troops and Arab militia allies have raped many tens of thousands of non Arab/African ("black") women.

29. The term "victim" refer to those who have been recently assaulted and the term "survivor" refer to those further along in recovery. Some researchers and advocates have called for using the term "survivor" rather than "victim" to emphasize the inherent strength required to recover from rape; others recommend using the term "victim". In this paper, these terms are used interchangeably to reflect both the violent nature of this crime (hence "victim") and the long-term work of recovering from such violence (hence "survivor").

${ }^{30}$. Soldiers use rape to extract information from women, also use as a method of torture or as an instrumental of war ${ }^{31}$. UN reports and reports from human rights observers and humanitarian organizations on the ground in Darfur. The conflict is between Sudanese government \& rebel groups some reported that the attacks are of Arab men upon non-Arab or African women (in its 2004 study, Amnesty International found only one instance in which rebel forces from the Fur, Massalit, or Zaghawa non-Arab or African ethnic groups were responsible for rape). A woman who was raped by five soldiers when she was traveling to the market at Abdu Shakur, North Darfur to get food, told Human Rights Watch that they ordered her off her donkey. When she refused she was whipped and then raped by all five men. She said: 'They were regular soldiers, with no rank. They wore army uniforms and one had a Kalashnikov [assault rifle]. The police have red caps. There were two with red caps but the others were bareheaded. They whipped me with two whips, used by three men.I said nothing, I could not scream. I was raped by all five. I did not report the rape because they were government soldiers."” 
- All sides of the conflict( the Sudanese security forces, militias \&rebel groups ) committed violations of international humanitarian law, including rape, particularly around camps for internally displaced persons (IDPs).

- Government continuously refuses to acknowledge the responsibility for practicing such crimes \& refuse to accept or agrees \& rejects \& negatively reply, despite the UN Security Council's futile "demand" that the regime disarm the Janjaweed and bring its leaders to justice.

- There Nemours of contradicting reports about the number of the cases from UN agencies \& Non governmental organizations ${ }^{32}$ there no clear idea about the number of women and girls who have been raped in Darfur ${ }^{33}$.

- There tremendous amount of reports (evidence, information \& data )published on ethnical \& racist animus in sexual attacks in Dar Fur conflict ${ }^{34}$ regardless of it`s objectivity.

- There reports about critical physical and psychological situation to receive treatment ${ }^{35}$

- From the recorded reports rapes have occurred during such necessary foraging for cooking fuelseeking water. $^{36}$

- limited ability-of police (lack of the basic tools and political will for responding to rape crimes and conducting investigationsmany exhibit an antagonistic and dismissive attitude toward women and girls. ) to investigate crimes committed by soldiers or militia, who often gain effective immunity under laws that protect them from civilian prosecution.

\begin{abstract}
32. Gingrich and Leaning report: "a Darfuran nongovernmental organization has documented 9,300 cases of rape, although other observers on the ground have argued that the number of rapes is closer to double that figure." Associated Press reported from Nyala (May 26, 2007): "UN workers say they registered 2,500 rapes in Darfur in 2006, but believe far more went unreported. The real figure is probably thousands a month, said a UN official.Sheiks in Kalma(is a displacements ' camp in south Dar Fur) said they report over a dozen rapes each week. Human rights activists in South Darfur who monitor violence in the refugee camps estimate more than 100 women are raped each month in and around Kalma alone.
\end{abstract}

${ }^{33}$ Because of the extraordinary reticence \& for religious and cultural reasons rape is a sensitive - with an eye in particular to how the Muslim world would receivereports on the subject , "Women will not tell easily if they have been raped. In their culture it is a shame. Women hide this in their hearts

${ }^{34}$ There many reports indicated that rape and sexual violence have a strong racial/ethnic animus in Darfur. already done (for example, political scientist Alan Wolfe offers displays a painfulignorance in speaking on this issue: see Dissent Magazine (January 26, 2012). Gingrich and Leaning also report on the racial/ethnic animus in the accountsof rape coming from non however, It is widely reported that during the attacks, the Janjaweed often berated the women, calling them slaves, telling them that theywould now bear a 'free child,' and asserting that they (the perpetrators) are wiping out the non-Arabs .

${ }^{35}$. Individual reports by Human Rights Watch, "Sexual violence and its consequencesamong displaced persons in Darfur and Chad," (April 2005)(were threatened with physical torture if they would testify with any information toany human rights organization or news agency).Survivors of sexual violence in Darfur have no meaningful access to redress. They fear the consequences of reporting their cases to the authorities and lack the resources needed to prosecute their attackers. See Eric reeves . Raping Girls in Darfur: A Continuing Weapon of War 01/21/2016 04:42 pm ET | Updated Jan 21, 2016

${ }^{36}$.Families, in orderto sustain themselves, have to continue collecting wood, fetching water or working their fields. In doing so, women have to make a terriblechoice, putting themselves or their children at risk of rape, beatings or death as soon as they are outside the camps, towns or villages. See: MSF, "The Crushing Burden of Rape: Sexual Violence in Darfur," for more details see .from Annex V: Rape of Women and Girls in Darfur - March 2012E. Reeves, These Are Women From An Internally Displaced PersonsCamp In Darfur: Not only must they make long trips for water in many places, but they must travel increasing distances to collect firewood thisexposes them to sexual assault by militia forces, and increasingly opportunistic paramilitary groups. Men and boys could not accompany the women, asthey would be killed rather than "merely" raped. This sense of powerlessnesson the part of the husbands, brothers, and sons of these women has created intense anger and frustration. 
- The major constrains to redress the incidents of rape cultural attitudes inhibited women from talking about what had happened to them ${ }^{37}$

- the international community is essentially silent ${ }^{38}$

The previous studies on this issue:-

There a few human rights publications, magazines, \& books have been produced to cover the issue of sexual violence in reference to Dar Fur conflict : for example: Halima Bashir, Tears of the Desert: A Memoir of Survival in Darfur (Random House, 2009).Bashir, a Zaghawa woman trained as a doctor, was herself savagely raped and tortured because of her courageous medical response to the mass rape of school girls in North Darfur. This searing account takes the reader to the very heart darkness in Darfur conflict.

One of the very earliest human rights accounts of what had already reached epidemic proportions. Report was written by Amnesty is authoritative, based on very substantial field research, and compelling in its analysis and framing of issues in terms of international humanitarian and human rights law. Eric Reeves Madeline Zehnder, research and editing Rape of Women and Girls in Darfur March 2012 , An Archival History of Greater Sudan, 2007 - 2012 . M'edecins Sans Fronti'eres/Doctors Without Borders (MSF) in its clinically informed study: "The Crushing Burden of Rape: Sexual Violence in Darfur" (Amsterdam, March 8, 2005). Without international protection, girls as young as eight will continue to experience the most vicious form of sexual violence. MSF provides all too many horrific examples: Another study of sexual violence in Darfur was published in 2011 Written by Tara Gingrich, JD,MAand Jennifer Leaning, MD, SMH, "The Use of Rape as a Weapon of War in the conflict in Darfur, Sudan" (October 2004) was prepared for the US Agency for International Development/ OTI under the auspices of the Harvard School of Public Health and the Francois-Xavier Bagnold Center for Health and Human Rights. \& many literature review from websites such as Physicians for Human Rights Report: http://darfuriwomen.phrblog.org/nowhere-to-turn/ These Are Women From An Internally Displaced Persons, Gingerich and Leaning report: http://reliefweb.int/node/411176, HRW report, 2005: http://reliefweb.int/node/411952, MSF report: http://tinyurl.com/8vtonu8, Congressional Testimony by Eric Reeves: http://tinyurl.com/983mnquHRW Report, 2008:http://www.hrw.org/node/62269/section/1

From the above literature review one can conclude that sexual violence is undeniable in Dar Fur conflict ${ }^{39}$. there sexism violation, abuses, crimes against humanity, threatened, injury, death, psychological harm, physical harm. they died, they abandoned or disavowed by shamed families and husbands. The consequences of conflict often breed nothing but misery,

In spite of the fact that international community despite its efforts ${ }^{40}$ : On March 31, 2005, the United Nations, in Security Council resolution 1593 , referred the situation in Darfur to the prosecutor of the International Criminal Court (ICC), stating that "the Government of Sudan and all other parties to the conflict in Darfur, shall cooperate

37. Cultural factors do influence the way that women react to sexual violence and other traumatic experiences. In many cultures, particularly those in which sexual purity is highly valued, women frequently find it difficult to talk about sexual violence. However, many women in all cultural contexts want to tell their stories, provided that certain measures are taken to minimize the associated trauma.

${ }^{38}$. A time when American civil society enthusiastically took on the cause of Darfur. So great was the campaign to "save Darfur" that even politicians felt an obligation to respond. During his campaign for president, Barack Obama called Darfur a "stain on our souls," vowing that as president, "I don't intend to abandon people or turn a blind eye to slaughter." Reporting on Darfur, UN Secretary General Ban Ki-moon sometimes omits any mention of sexual violence in Darfur. And the Obama administration, despite the strong words of candidate Obama, says nothing of consequence.

39. Physicians for Human Rights Report: http://darfuriwomen.phrblog.org/nowhere-to-turn/ COMPROMISING WITH EVIL: An Archival History of Greater Sudan, 2007 - 2012

Annex V: Rape of Women and Girls in Darfur - March 2012

${ }^{40}$.the international community represented in UN \& it`s agencies \& AMIS \& Arab union \& countries especial Qatar country . in addition to the decisions of security council inconflict affected areas the articles concerning sexual violence (1325) in (2000), (1889) in (2009), (1820) in (2008), (1888) in (2009), (1960) in 2010) 
fully with ... the Court and the Prosecutor pursuant to this resolution. .." Following the referral, the ICC decided to open investigations into the situation in Darfur. ICC Prosecutor Luis Moreno-Acampo said: "[The investigation] will form part of a collective effort, complementing African Union and other initiatives to end the violence in Darfur and to promote justice. Traditional African mechanisms can be an important tool to complement these efforts and achieve local reconciliation." unfortunately has failed in its quest to protect the unarmed civilians in Darfur from daily deadly attacks The pre-trial chamber of the ICC issued an arrest warrant on March 4, 2009 for the current president of Sudan. was charged with five counts of crimes against humanity in violation of the Rome Statute include rape in violation of Article 7 (1) $(\mathrm{g})^{41}$

On the other hand the United Nations Security Council has passed numerous resolutions to protect civilians in Darfur including the deployment of UNAMID peacekeeping forces in the region but to no avail. Although in both Dar Fur peace agreements ${ }^{42}$ (Abuja 2005) \& El - Doha (2010) there were essential articles of human rights stated " No person shall be subjected to torture or undergo cruel, inhuman treatment " . " The privacy of all person shall be respected \& no person shall be subjected to coercive invasion of her /his privacy family life" .in dealing with Sudan's ongoing National Dialogue(January 2014-2016) they are saying that it aims to map Sudan's future by bringing together all Sudanese regardless of their political and ideological differences to frankly and thoroughly discuss all key issues and problems of Sudan including identity, economy, system of governance, and freedoms.

With great stick to the out puts one believe that to hold a genuine dialogue demand several process such as stopping the war, delivering humanitarian assistance, allowing freedoms and releasing political detainees and convicts and then coming together in a forum .whether we optimistically adopted it or pessimistically criticize it to come in real context need a great efforts of transparency \&accountability and compensation for crimes committed \& pardons.

In concluding this part of the article The tragic reported statements of rape survivors of ( Tawilah) ${ }^{43}$ (Tabt) $)^{44}$ give a horrific illustration of the daily reality of women and young girls in Darfur, the primary victims of this form of violence. Rape in the context of war serves to create fear, shame, and demoralization among many others in addition to the individual who has been directly assaulted. In adopting Gingrich and Leaning's account of "the strategic use of rape," and its particular relevance for Darfur: the extreme threat of rape continues for as many as 1.5 million women and girls. This has immense implications for the populations of Darfur, it create a sense of fear in the civilian population in order to restrict freedom of movement and economic activity. The consistency and implacability of the Janjaweed attack pattern has cast a massive shadow of fear across Darfur. Word of the rapes of the non-Arab population has spread to all those who have not yet been struck. This fear translates in to a siege situation, whereby no one ventures outside the confines of the village unless it is absolutely necessary.Instill flight to facilitate capture of land and killing of male civilians. The modus operandi of the Janjaweed and Government of Sudan military attacks on Dar furian villages has become known across the region. Defiance in the face of the onslaught simply leads to death.

\footnotetext{
${ }^{41}$.Matthew Happold, "Darfur, the Security Council, and the International Criminal Court" 55 The International and Comparative Law Quarterly 226 (2006)

42. Dar Fur peace agreement Abuja 5 July 2005 \& Dar Fur peace agreement Eldoha 2010

43. In an attack on 27 February [2004] in the Tawilah area of northern Darfur, over 200 girls and women raped some by up to 14 assailants and in front of their fathers who were later killed. A further 150 women and 200 children were abducted. For more See: Tara Gingrich, JD, MA and Jennifer Leaning, MD, SMH, "The Use of Rape as a Weapon of War in the conflict in Darfur, Sudan," (October 2004). see :Alliance For Direct Action Against Rape In Conflict and Crises. See : Jan Egeland, UN Under-Secretary for Humanitarian Affairs, Rape and Sexual Violence: The View from June 2005

44. The village of Tabit, in North Darfur, Sudanese army forces raped more than 200 women and girls in October 2014, Human Rights Watch said . The 48-page report, "Mass Rape in Darfur: Sudanese Army Attacks Against Civilians in Tabit," documents Sudanese army attacks in which at least 221 women and girls were raped in Tabit over 36 hours beginning on October 30, 2014. Allegations of mass rape first surfaced in a November 2 report by Radio Dabanga.
} 
Rape as traumatic experience ${ }^{45}$ : There many researches documented and explained the trauma of rape on victims' lives. Immediately following a rape, most women are in a state of shock. They may or may not be physically injured but all have been through a life threatening situation and will need time and support to recover. Women may react differently to an assault. Some women may become hysterical while others go through a denial stage and appear calm and in control. The circumstances surrounding the rape may vary as well, but all victims feel varying degrees of fear ${ }^{46}$ guilt, shame, , anxiety, tension, crying spells, an exaggerated startle response, depression, anger , grief, irritability, aggressively, , sleeping problems, nightmares/ flashbacks, Existential difficulties \& reactions include meaninglessness, no hope for the future, emptiness, apathy, helplessness, lack of continuity Rape comes as a devastating shock, destroying victims' abilities to maintain the important illusion of personal safety and invulnerability, a woman may feel guilt, wondering why she was the victim. She may question whether she really did ? ask for it, or lead someone to the wrong impression. She may also be embarrassed about what other people think of her. These feelings may cause her to avoid sexual relationships for a time. And finally the anger that her personal freedom was violated and the man is walking around free takes over. Anger may take different forms but most psychologists feel that it is the emotion that can lead to a successful emotional recovery. It is at this stage that the woman wants to fight back and get her life in order. However there is the possibility this anger may be projected onto others not involved. Men need to be aware of the feelings a woman experiences. The woman who denies the event and says she is OK needs the same kind of counseling and support as other women, perhaps more so as she is repressing her true feelings.

Much of the early research in the sexual assault literature documented the kinds of post-assault psychological problems rape survivors experience. Post- traumatic stress ${ }^{47}$ : is a clinical diagnosis that captures the psychological aftermath of both chronic and one-time violence and trauma. . Victims respond to these traumatic experiences through alternating sequences of intrusions and avoidance. Intrusions are the reliving of the trauma: flashbacks, nightmares, and repeated thoughts that won't leave one's mind. Avoidance refers to how victims isolate themselves from reminders of the traumatic event to prevent becoming emotionally overwhelmed: emotional numbing, withdrawing from others, intellectualizing, distracting themselves by engaging in drug/alcohol use or other high-risk behaviors. Other responses common with PTSD include dissociation, increased arousal, irritability, angry outbursts, hyper vigilance, sleep disturbances, and other physical health. The PTSD clinical framework is based on the assumption that this psychological distress is a normal reaction to an unusual event. These psychological reactions occur because the traumatic event is outside normal human experiences (e.g., war, violent crime). Virtually anyone would find such occurrences distressing, hence PTSD is viewed as a normal, albeit distressing, reaction to abnormal events $^{48}$. Rape victims constitute the largest single group of PTSD suffers ${ }^{49}$. Even when evaluated several years after the assault, survivors are more likely to have a serious psychiatric diagnosis, including major depression,

${ }^{45}$. Traumatic experience is a situation that goes beyond an ordinary experience \& that is a stressful event for almost anybody. On the other hand Traumatic events are incidents that lie outside the range of usual human experience and are so powerful that they are capable of overwhelming any person's normal coping abilities and causing severe stress reactions. See : The secret of war crime time.com/war-and-rape.

${ }^{46}$. The fear a woman feels may weave through all aspects of her life. More than likely she was attacked going about her business, feeling safe in her world. Once that security is invaded the woman may be fearful about the once routine activities of her daily life. She may approach strangers and even friends and acquaintances with a new

caution.

${ }^{47}$. American Psychiatric Association (1994). Diagnostic and statistical manual of mental disorders: DSM IV. Washington, DC: Author.

${ }^{48}$. Feminist researchers raise concern that the PTSD framework mislabels a societal problem as an individual onethe trauma of rape is a psychological problem with societal roots . for more see : Brown, L.S. (1994). Subversive dialogues: Theory in feminist therapy. New York: Basic Books.

${ }^{49}$. Foa, E.B., Steketee, G., \&Olasov, B. (1989). Behavioral/cognitive conceptualization of post-traumatic stress disorder. Behavior Therapy, 20, 155-176. 
alcohol abuse and dependence, drug abuse and dependence, generalized anxiety, obsessive-compulsive disorder, and post-traumatic stress disorder ${ }^{50}$

Social impacts of rape : In a culture that places high value on virginity and chastity as Darfur, the burden inflicted by rape is particularly devastating and enduring. Tear apart the community, by breaking family and community bonds . Reports of rapes are replete with statements made by the victims are not always met with supportive responses. However, rape survivors experience a variety of negative social reactions from informal and formal help sources (e.g., being doubted, being blamed). With respect to seeking post-rape community services, a growing body of research suggests that rape survivors are often denied help by their communities, and what help they do receive, often leaves them feeling blamed, doubted, and re-victimized ${ }^{51}$. Since in Dar fur according to customs \& norms \& religion women almost represent the honest of the family \& tribe \& community Family acceptability to rape incident is beyond illustration , the doubt, disgusting, trust less, avoidance, social isolation , ostracism from close friends on the other hand family members may feel . fused, angry, powerless, and frustrated Recent findings also suggest that survivors struggle not only with how the assault has directly affected them, but also with how it is affecting those close to them (e.g., husbands, significant others, friends) ). Rape survivors may be struggling not only with their own reactions to the assault, but also with how it is affecting those close to the. ${ }^{52}$ Furthermore, formal sector of protection :( Police/ hospital/ court/ rape crisis centers) . In most locations the patrol officer on call will respond to a complaint by a rape victim. This officer has probably had little, if any, training in dealing with rape. Later, the case is referred to an investigator who most likely works with all types of assaults most investigations are still conducted by males.

Unfortunately, many police officers are antagonistic toward the female rape victim. They may feel embarrassed themselves at having to question a woman about a sexual assault. Very often police questioning focuses on the woman having brought on the attack herself by her dress, her inviting a man to her house, accepting a ride from a man, or by her past sexual experiences. The officer may dwell on the sexual aspect of the rape, asking her to describe her feelings during the attack, the rapist`s genitals, or the position in which he raped her.

The Hospital. Whether or not a rape victim intends to report an attack to the police, she should obtain medical care. When a woman who has been raped arrives at a hospital, medical personnel have a two-fold responsibility. They must treat the patient and also provide evidence for the police that a rape did occur.

In addition to checking a victim`s entire body for injury, a doctor should explain to her when she must return for pregnancy and venereal disease tests. A doctor will check for the presence of semen in the vagina as well as on other parts of her body and clothes. A rape victim should not wash herself before going to the hospital, and her clothing should be made available for the investigation. Doctors in hospital emergency rooms, where most rape victims are taken, do not always react sympathetically. Here, too, women frequently report they are subjected to hostile and irrelevant questions.

The Courts. A woman may report an assault to the police but choose not to press charges . Many victims describe their court experiences as unpleasant and difficult.

While the police and medical personnel often subject a rape victim to unfair questions, in the courtroom she must endure even more.

${ }^{50}$.Koss, M.P. (1993). Rape: Scope, impact, interventions, and public policy responses. American Psychologist, 48 , 1062-1069.

${ }^{51}$. Campbell, R., Sefl, T., Barnes, H.E., Ahrens, C.E., Wasco, S.M., \&Zaragoza-Diesfeld, Y. (1999). Community services for rape survivors: Enhancing psychological well-being or increasing trauma? Journal of Consulting and Clinical Psychology, 67, 847-858.

52. Marcia Cohen and Sherrie H. McKenna(2016) Psychology, Prevention and ImpactYale-New Haven Teachers Institute Home 
The victim will often be attacked by the defense attorney on three major issues. (1) Consent. How much did she resist? Many rapists have been released on the grounds that a rape did not occur because the victim did not struggle.

(2) Corroboration. Requiring another witness testify that the rape took place or that there is some evidence such as the victim`s injuries or the presence of semen. If the victim was not harmed or she delayed reporting the rape so that the semen had disappeared, there would be no physical evidence and the case might be dismissed.

(3) Chastity. The victim`s past sexual behavior is often presented as evidence on behalf of the defendant. Testimony by a rape victim who admits to having sexual relations with someone to whom she is not married is used as proof that she is immoral and therefore, she is likely to have consented to intercourse .Conversely, the past crimes of the defendant are not admissible as evidence. Acquittals in jury trials have been based on the admission by the victim that she was walking alone, that she was hitchhiking, that she showed no evidence of physical abuse, that she was dressed seductively, (thus, why would anyone rape her?)

Rape crisis centers:(there none in Dar Fur context) Provide services for the rape victim. include a telephone answering line, group and individual counseling, escort service, self-defense classes, and women`s discussion groups. Since most of these centers have limited funds, they rely on volunteers to assist in their work.

Psycho- social support for victims of rape: -There are no easy answers when discussing how to support a woman who has been raped to cope with the trauma she has experienced psychologically \& socially. Doctors may heal the physical wounds but the psychological scars may be less visible and more difficult to overcome \& the wound of the social isolation \& dealing with suspicious eyes from the community surrounding the victims. Psychosocial support as terminology in psychosocial psychology consists of two un separated part implements that the frustrated, fragmented, feeling of guiltiness, un confinement, fear, anxiety, irritability, psych of survivor need care, help, assistance, support, guidance from others whether family, friends, community service providers . On the other hand social support is the perception and actuality that one is cared for, has assistance available from other people, and that one is part of a supportive social network. These supportive resources can be emotional ( nurturance), tangible ( financial assistance), informational ( advice), or companionship ( sense of belonging) and intangible ( personal advice).Psychosocial support is studied across a wide range of disciplines including psychology, medicine, sociology, nursing, public health, and social work.

Many studies have been dedicated specifically to understanding the effects of psychosocial support in individuals with posttraumatic stress disorder (PTSD). In a study by Haden et al., when victims of severe trauma perceived high levels of social support and engaged in interpersonal coping styles, they were less likely to develop severe PTSD when compared to those who perceived lower levels of social support. These results suggest that high levels of social support alleviate the strong positive association between level of injury and severity of PTSD, and thus serves as a powerful protective factor. In general, data shows that the support of family and friends has a positive influence on an individual's ability to cope with trauma. In fact, a meta-analysis by Brewin et al. found that social support was the strongest predictor, accounting for $40 \%$, of variance in PTSD severity ${ }^{53}$

This part of article reviews research findings on kinds of psycho social support for survivors. Before we provide that we must bear in mind that there very few victims ${ }^{54}$ seek treatment whether mental or psychological or social. Rates of mental health services utilization vary across studies, but it appears that approximately $25 \%-40 \%$ of victims seek treatment ${ }^{55}$

\footnotetext{
${ }^{53}$.Jump up ^ Brewin, C. R.; Andrews B.; Valentine, J. D. (2000). "Meta-analysis of risk factors for posttraumatic stress disorder in trauma-exposed adults". Journal of Consulting and Clinical Psychology 68 (5): 748-766. doi:10.1037/0022-006x.68.5.748.

${ }^{54}$. One of the most recent and telling studies of rape in Darfur (2012) revealed that 49 percent of girls and women seen by a treatment center in Nyala, South Darfur had been raped.See Eric reeves Raping Girls in Darfur: A Continuing Weapon of War 01/21/2016 04:42 pm ET| Updated Jan 21, 2016

${ }^{55}$. Rebecca Campbell, Debra Patterson and Lauren F. Lichty ( Oct 10, 2005) Trauma, Violence, \& Abusehttp://tva.sagepub.com/The Effectiveness of Sexual Assault Nurse Examiner (SANE) Programs : A Review of Psychological,
} 
Since public health approach is interdisciplinary, drawing upon knowledge from many disciplines including, epidemiology, sociology, psychology, criminology, education and economics. Because all forms of violence are multi-faceted problems, the public health approach emphasizes a multi-sectorial response.

.taking prevention ${ }^{56}$ (of sexual violence) approach of public health as umbrella in dealing with the strategies for psychosocial support \& bearing in mind the three types of prevention : The primary prevention of SV since war continuous it`s impossible to stop rape of women because it`s war area but one emphasize on the ability to identify underlying causes rather than focusing upon.

1. Defining the problem conceptually and numerically, using statistics that accurately describe the nature and scale of violence, the characteristics of those most affected, the geographical distribution of incidents, and the consequences of exposure to such violence.

2. Investigating why the problem occurs by determining its causes and correlates, the factors that increase or decrease the risk of its occurrence (risk and protective factors) and the factors that might be modifiable through intervention.

3. Exploring ways to prevent the problem by using the above information and designing, monitoring and rigorously assessing the effectiveness of programmers through outcome evaluations.

4. Disseminating information on the effectiveness of programmers and increasing the scale of proven effective programmers. Approaches to prevent violence, whether targeted at individuals or entire communities, must be properly evaluated for their effectiveness and the results shared. This step also includes adapting programmers to local contexts and subjecting them to rigorous re-evaluation to ensure their effectiveness in the new setting. Rape \& other sorts of sexual violence are no longer issues for lawyers or military personnel or politicians they are for public health workers \& civic organizations \& high academic institutions to study \& drift scientific solution

The human rights approach is based on the obligations of states to respect, protect and fulfill human rights and therefore to prevent, eradicate and punish violence. The Convention on the Elimination of All Forms of Discrimination Against Women, for example, requires that countries party to the Convention take all appropriate steps to end violence against women. The Convention on the Rights of the Child in its Article 19 states that States Parties shall take all appropriate legislative, administrative, social and educational measures to protect the child from all forms of physical or mental violence, injury or abuse, neglect or negligent treatment, maltreatment or exploitation, including sexual abuse, while in the care of parent(s), legal guardian(s) or any other person who has the care of the child.

\section{The role of women organizations in psyche - social support for victims of rape:-}

In spite of the efforts which offered by the international agencies United Nation African Mission In Dar Fur in funding \& managing \& monitoring \& creating active co- ordinated multi-sectorial action implementing all actors (community services, health, protection, security) \&the presence of women in mission of UNAMID make a positive impact ( in Darfur's cultural context, women typically would not report rape or talk about it with male authority figures. when they see woman, with peace keeping mission their faces light up and find it easier to form a connection) . implementing local women NGOs in the process of psychosocial support may bring crucial impacts for victims of rape in Dar Fur. There are many women non-governmental organizations [WNGOs], that are dedicated to provide assistance to victims of rape, domestic violence, sexual harassment in IDPs camps. These organization work in collaboration with International organizations (INOs) by providing projects implementing various sub activities drifted from their objectives \& according to mandates of INGOs complete the approval for

56.. Prevention strategies can be classified into three types:

- Primary prevention - approaches that aim to prevent SV before it occurs.

- Secondary prevention - approaches that focus on the more immediate responses to SV, such as pre-hospital care, emergency services or treatment for sexually transmitted infections following a rape.

- Tertiary prevention - approaches that focus on long-term care in the wake of SV, such as rehabilitation and reintegration, and attempt to lessen trauma or reduce long-term disability associated with. 
funding such projects it`s not an easy process because there complexity and variety of factors: The local women organizations lack adequate knowledge. There many restrictions in tickled such issue rape survivals from government authority security \& Human Affairs Commission at national \& state level (HAC). In addition to the technical \& qualification (standard) demands of INGOs in (language, literature review of such issues methodology, illustration of budget measuring out comes, stages of execution of the project \& it`s out puts). Lacking inadequate funding, training, \& lack of robust data collection and management systems; and lack of formal evaluation. In spite of the mention difficulties the women civil society organizations since the current conflict of Dar Fur play fundamental role in dealing with women issues specifically violence against women . WNGOs are the best focal group that support rape victims and assist women victims of rape, psychosocially, however the following points can rationalize our justifications:

- The sense of sisterhood from one who speak your own language $\&$ know your tribe $\&$ area because some victim-survivors are particularly vulnerable by virtue of their ethnicity, language, minority, refugee or indigenous status, their age, or their disability status and ensure that special attention, intervention or protection required WNGOs can represent such support.

- "The survivals may look at WNGOs as their peers. they learn about each other's lives, lend a helping hand where possible and advise them on issues that affect their lives,"

- Victims often experience social stigma associated with rape and sexual violence and may be ostracized by their families and community. Women organizations can report the cases of such families.

- Empower individual women who are victims of violence. The sense of control, autonomy, safety and support provided by WNGOs reinforce the victims \& regain confidence to themelves

- WNGOs can stand against suspicious eyes weather from males or female \& strongly defense \& support the fragile \& helpless victims .

- The sense of belonging and intangible ( personal advice) which provide by WNGOs may create in victims the hope for future .

- The trial can be a harrowing experience for victims if their testimony and character are subjected to hostile questioning, WNGOs can psychologically support to stand without any fear her head held highly.

\section{Recommendations:-}

- Increasing the visibility of sexual violence $\&$ highlight the right of women to be protected against rape through its criminalization and prevention.

- civil society women organizations should articulate requests for: recognition by the state rape as a serious crime;

- challenge entrenched and pervasive cultures of sexual violence against women:

- Health services should arrange for protection, shelter and/or social service support if the victim-survivor has no safe place to go.

- Information for on-going care and arrangements for follow-up appointments should be clearly communicated during the health consultation.

- In collaboration with other sectors should develop social media to communicate information about the service to underrepresented communities including why, when and how to access.

- The key challenge in preventing violence against women is the limited evidence base o call for better data collection and monitoring systems.

- Treat the victim-survivor with respect and sensitivity so as to avoid secondary re- victimization and are victimcentric, placing the health, safety, dignity, privacy and autonomy needs of the victim-survivor at the Centre of the practice

- Training women's organizations and potential representatives in, advocacy and in-depth understanding of SRC 1820 provisions; and establish gender units in peacekeeping operations to ensure that women are able to articulate their concerns.

\section{Margins \&references:-}

1. American Heritage Dictionary of the English Language, Fifth Edition (2011).

${ }^{1}$. The invasion was committed by force, or by threat of force or coercion, such as that caused by fear of violence, duress, detention, psychological oppression or abuse of power, against such person or another person, or by taking advantage of a coercive environment, or the invasion was committed against a person incapable of giving genuine consent.[The concept of "invasion" is intended to be broad enough to be gender-neutral and the definition is understood to include situations where the victim may be incapable of giving genuine consent if affected by natural, 
induced or age-related incapacity. see : Minzoni - Deroche, Angela (November 2005). "Rape as a tactic of war - Advocacy Paper" (PDF). Caritas France.[dead $\operatorname{link}[$

3. Jump up to: a b Elements of Crimes at the Way back Machine (archived December 1, 2008). PDF: Archive copy at the Internet Archive PDF. International Criminal Court

${ }^{4}$.The Uniform Crime Reporting (UCR) Program has been the starting place for law enforcement executives, students of criminal justice, researchers, members of the media, and the public at large seeking information on crime in the nation. The program was conceived in 1929 by the International Association of Chiefs of Police to meet the need for reliable uniform crime statistics for the nation. https://ucr.fbi.gov/

5. The fact that rapes regularly occur during war time has been presented as evidence of the assessment of victim vulnerability and decreased likelihood of detection. Men in war are likely to have lowered costs of committing rape, because punishment or retaliation by the victim, the victim's family, or society, are particularly is less likely. For more details see: Gottschall, J. (2004). Explaining wartime rape. The Journal of Sex Research, 41, 129-136.

6. UN agencies estimate that more than 60,000 women were raped during the civil war in Sierra Leone (1991-2002), more than 40,000 in Liberia (1989-2003), up to 60,000 in the former Yugoslavia (1992-1995), and at least 200,000 in the Democratic Republic of the Congo since 1998.In Rwanda, between 100,000 and 250,000 women were raped during the three months of genocide in 1994. See: Overview of the worldwide best practices for rape prevention and for assisting women victims of rape www.europarl.europa.eu/RegData/etudes/.../IPOLFEMM_ET(2013)493025_EN.pdf

7. Rang ham, R., \& Peterson, D. (2007). Demonic males. New York: Houghton Mifflin. For more see Greenfield, L. (1997). Sex offenses and offenders. Washington, DC: Bureau of Justice Statistics, U.S. Department of Justice.

${ }^{8}$. individuals with this belief often unintentionally place the victim on trial. Her motives, her dress and her actions become suspect not only to law enforcement officials but also to her family and friends. The woman`s credibility may be questioned and her sexual activity and private life may be made public. Perhaps because of the guilt, embarrassment and humiliation.

${ }^{9}$ Evolutionary psychology is a powerful heuristic tool that allows researchers to develop and test novel hypotheses about complex behaviors such as rape for a more complete review, see Buss, 2004; Too by \&Cosmides, 2005)

10. although within the feminism movement there different feminists( liberal, radical, social) \& several theoretical models

11. Marcia Cohen and Sherrie H. McKenna .( 2016) . Rape: Psychology, Prevention and Impact, Yale-New Haven Teachers Institute Home

${ }^{12}$. except in those rare instances of homosexual rape,

13 . Conquering the riches and property of an enemy was regarded as legitimate reason for war in itself. Women were included with "property", since they were considered under the lawful ownership of a man, whether a father, husband, slave master, or guardian. ^ Jump up to: ${ }^{a b c}$ Askin (1997), pp. 10-21

14. ^ Jump up to: ${ }^{a b c}$ EijiTakemae, Robert Ricketts, Sebastian Swann, Inside GHQ: The Allied Occupation of Japan and Its Legacy. p. 67. (Google .books)

15 . Jump up ^Askin (1997), p. 13

16. Jump up to: ${ }^{a b c}$ Askin (1997), pp. 10-21

17. Jump up ^Askin (1997), pp. 23-24

18 . ^ Jump up to: ${ }^{a b}$ Abou El Fadl, Khaled (2001). Commentary: Terrorism Is at Odds With Islamic Tradition. LA Times. Retrieved 11 July 2011

19. ^ Jump up to: ${ }^{a b}$ Askin (1997), p. 27

20. ^ Jump up to: ${ }^{a b}$ Askin (1997), p. 28

22. Jump up ^Askin (1997), p. 33

23. ^ Jump up to: ${ }^{a b}$ Askin (1997), pp. 35-36

24 . The trial of General Matsui who had the command of Japanese forces. Matsui was convicted of war-crimes and crimes against humanity based in part on evidence of rape committed by his troops.see

${ }^{25} \wedge$ Jump up to: ${ }^{a b}$ Askin (1997), p. 17

26 . Statement said by NavanethemPillay. United Nations High Commissioner for Human Rights

27 . Jump up ^"SECURITY COUNCIL DEMANDS IMMEDIATE AND COMPLETE HALT TO ACTS OF SEXUAL VIOLENCE AGAINST CIVILIANS IN CONFLICT ZONES, UNANIMOUSLY ADOPTING RESOLUTION 1820 (2008)". United Nations. Retrieved 2012-11-09 
28 Darfur is a region in Sudan, that had a population of approximately 6 million. In 2003, two rebel groups, Sudan Liberation Army/Movement (SLA/M) and the Justice and Equality Movement (JEM) launched a full-scale rebellion against the Sudanese government for reasons of ongoing economic marginalization and insecurity.

The Sudanese government responded to the rebellion with the Arab militia (El- Janjaweed) with violent attacks on villages throughout the state. Since beginning in 2003 , an estimated 400,000 people have died directly or indirectly from the attacks.

deliberate and systematic extermination of a national, racial, political, or cultural group. The violence in Darfur is racially based \& considered as the worst humanitarian crisis of the 21 st century.

${ }^{29}$. The term "victim" refer to those who have been recently assaulted and the term "survivor" refer to those further along in recovery. Some researchers and advocates have called for using the term "survivor" rather than "victim" to emphasize the inherent strength required to recover from rape; others recommend using the term "victim". In this paper, these terms are used interchangeably to reflect both the violent nature of this crime (hence "victim") and the long-term work of recovering from such violence (hence "survivor").

30. Soldiers use rape to extract information from women, also use as a method of torture or as an instrumental of war ${ }^{31}$. UN reports and reports from human rights observers and humanitarian organizations on the ground in Darfur. The conflict is between Sudanese government \& rebel groups some reported that the attacks are of Arab men upon non-Arab or African women (in its 2004 study, Amnesty International found only one instance in which rebel forces from the Fur, Massalit, or Zaghawa non-Arab or African ethnic groups were responsible for rape). A woman who was raped by five soldiers when she was traveling to the market at Abdu Shakur, North Darfur to get food, told Human Rights Watch that they ordered her off her donkey. When she refused she was whipped and then raped by all five men. She said: 'They were regular soldiers, with no rank. They wore army uniforms and one had a Kalashnikov [assault rifle]. The police have red caps. There were two with red caps but the others were bareheaded. They whipped me with two whips, used by three men. I said nothing, I could not scream. I was raped by all five. I did not report the rape because they were government soldiers."”

32. Gingerich and Leaning report: "a Dar furian nongovernmental organization has documented 9,300 cases of rape, although other observers on the ground have argued that the number of rapes is closer to double that figure." Associated Press reported from Nyala (May 26, 2007): "UN workers say they registered 2,500 rapes in Darfur in 2006, but believe far more went unreported. The real figure is probably thousands a month, said a UN official.Sheikas in Kalma(is a displacements`camp in south Dar Fur) said they report over a dozen rapes each week. Human rights activists in South Darfur who monitor violence in the refugee camps estimate more than 100 women are raped each month in and around Kalma alone.

${ }^{33 .}$ Because of the extraordinary reticence \& for religious and cultural reasons rape is a sensitive-with an eye in particular to how the Muslim world would receive reports on the subject, "Women will not tell easily if they have been raped. In their culture it is a shame. Women hide this in their hearts

34. There many reports indicated that rape and sexual violence have a strong racial/ethnicanimus in Darfur. already done (for example, political scientist Alan Wolfe offers displays a painful ignorance in speaking on this issue: see Dissent Magazine (January 26, 2012). Gingerich and Leaning also report on the racial/ethnic animus in the accounts of rape coming from non however, It is widely reported that during the attacks, the Janjaweed often berated the women, calling them slaves, telling them that they would now bear a 'free child,' and asserting that they (the perpetrators) are wiping out the non-Arabs .

35. Individual reports by Human Rights Watch, "Sexual violence and its consequences among displaced persons in Darfur and Chad," (April 2005) (were threatened with physical torture if they would testify with any information to any human rights organization or news agency).Survivors of sexual violence in Darfur have no meaningful access to redress. They fear the consequences of reporting their cases to the authorities and lack the resources needed to prosecute their attackers. See Eric reeves . Raping Girls in Darfur: A Continuing Weapon of War 01/21/2016 04:42 pm ET | Updated Jan 21, 2016

${ }^{36}$. Families, in order to sustain themselves, have to continue collecting wood, fetching water

or working their fields. In doing so, women have to make a terrible choice, putting themselves or their children at risk of rape, beatings or death as soon as they are outside the camps, towns or villages .see: MSF, "The Crushing Burden of Rape: Sexual Violence in Darfur," for more details see .from Annex V: Rape of Women and Girls in Darfur - March 2012 E. Reeves,These Are Women From An Internally Displaced PersonsCamp In Darfur : Not only must they make long trips for water in many places, but they must travel increasing distances to collect firewood this exposes them to sexual assault by militia forces, and increasingly opportunistic paramilitary groups. Men and boys could not accompany the women, asthey would be killed rather than "merely" raped. This sense of powerlessness on the part of the husbands, brothers, and sons of these women has created intense anger and frustration. 
37. Cultural factors do influence the way that women react to sexual violence and other traumatic experiences. In many cultures, particularly those in which sexual purity is highly valued, women frequently find it difficult to talk about sexual violence. However, many women in all cultural contexts want to tell their stories, provided that certain measures are taken to minimize the associated trauma.

38. A time when American civil society enthusiastically took on the cause of Darfur. So great was the campaign to "save Darfur" that even politicians felt an obligation to respond. During his campaign for president, Barack Obama called Darfur a "stain on our souls," vowing that as president, "I don't intend to abandon people or turn a blind eye to slaughter." Reporting on Darfur, UN Secretary General Ban Ki-moon sometimes omits any mention of sexual violence in Darfur. And the Obama administration, despite the strong words of candidate Obama, says nothing of consequence.

39. Physicians for Human Rights Report: http://darfuriwomen.phrblog.org/nowhere-to-turn/ COMPROMISING WITH EVIL: An Archival History of Greater Sudan, 2007 - 2012

Annex V: Rape of Women and Girls in Darfur - March 2012

${ }^{40}$.the international community represented in UN \& it's agencies \& AMIS \& Arab union \& countries especial Qatar country . in addition to the decisions of security council in conflict affected areas the articles concerning sexual violence (1325) in (2000), (1889) in (2009), (1820) in (2008), (1888) in (2009), (1960) in 2010)

41. Matthew Happold, "Darfur, the Security Council, and the International Criminal Court" 55 The International and Comparative Law Quarterly 226 (2006)

42. Dar Fur peace agreement Abuja 5 July 2005 \& Dar Fur peace agreement Eldoha 2010

43. In an attack on 27 February [2004] in the Tawilah area of northern Darfur, over 200 girls and women raped some by up to 14 assailants and in front of their fathers who were later killed. A further 150 women and 200 children were abducted. For more See: Tara Gingerich, JD, MA and Jennifer Leaning, MD, SMH, "The Use of Rape as a Weapon of War in the conflict in Darfur, Sudan," (October 2004). see :Alliance For Direct Action Against Rape In Conflict and Crises. See : Jan Egeland, UN Under-Secretary for Humanitarian Affairs, Rape and Sexual Violence: The View from June 2005

44. The village of Tabit, in North Darfur, Sudanese army forces raped more than 200 women and girls in October 2014, Human Rights Watch said . The 48-page report, "Mass Rape in Darfur: Sudanese Army Attacks Against Civilians in Tabit," documents Sudanese army attacks in which at least 221 women and girls were raped in Tabit over 36 hours beginning on October 30, 2014.

Allegations of mass rape first surfaced in a November 2 report by Radio Dabanga.

45. Traumatic experience is a situation that goes beyond an ordinary experience \& that is a stressful event for almost anybody. On the other hand Traumatic events are incidents that lie outside the range of usual human experience and are so powerful that they are capable of overwhelming any person's normal coping abilities and causing severe stress reactions. See : The secret of war crime time.com/war-and-rape.

46. The fear a woman feels may weave through all aspects of her life. More than likely she was attacked going about her business, feeling safe in her world. Once that security is invaded the woman may be fearful about the once routine activities of her daily life. She may approach strangers and even friends and acquaintances with a new caution.

47. American Psychiatric Association (1994). Diagnostic and statistical manual of mental disorders: DSM IV. Washington, DC: Author.

${ }^{48}$. Feminist researchers raise concern that the PTSD framework mislabels a societal problem as an individual onethe trauma of rape is a psychological problem with societal roots . for more see : Brown, L.S. (1994). Subversive dialogues: Theory in feminist therapy. New York: Basic Books.

49. Foa, E.B., Steketee, G., \&Olasov, B. (1989). Behavioral/cognitive conceptualization of post-traumatic stress disorder. Behavior Therapy, 20, 155-176.

50. Koss, M.P. (1993). Rape: Scope, impact, interventions, and public policy responses. American Psychologist, 48, 1062-1069.

51. Campbell, R., Sefl, T., Barnes, H.E., Ahrens, C.E., Wasco, S.M., \&Zaragoza-Diesfeld, Y. (1999). Community services for rape survivors: Enhancing psychological well-being or increasing trauma? Journal of Consulting and Clinical Psychology, 67, 847-858.

52. Marcia Cohen and Sherrie H. McKenna(2016) Psychology, Prevention and Impact Yale-New Haven Teachers Institute Home .

53. Jump up ${ }^{\wedge}$ Brewin, C. R.; Andrews B.; Valentine, J. D. (2000). "Meta-analysis of risk factors for posttraumatic stress disorder in trauma-exposed adults". Journal of Consulting and Clinical Psychology 68 (5): $748-766$. doi:10.1037/0022-006x.68.5.748. 
54 . One of the most recent and telling studies of rape in Darfur (2012) revealed that 49 percent of girls and women seen by a treatment center in Nyala, South Darfur had been raped. See Eric reeves Raping Girls in Darfur: A Continuing Weapon of War 01/21/2016 04:42 pm ET| Updated Jan 21, 2016

55 . Rebecca Campbell, Debra Patterson and Lauren F. Lichty ( Oct 10, 2005) Trauma, Violence, \& Abuse http://tva.sagepub.com/The Effectiveness of Sexual Assault Nurse Examiner (SANE) Programs : A Review of Psychological,

56.. Prevention strategies can be classified into three types:

- $\quad$ Primary prevention - approaches that aim to prevent SV before it occurs.

- Secondary prevention - approaches that focus on the more immediate responses to SV, such as pre-hospital care, emergency services or treatment for sexually transmitted infections following a rape.

- Tertiary prevention - approaches that focus on long-term care in the wake of SV, such as rehabilitation and reintegration, and attempt to lessen trauma or reduce long-term disability associated with. 